\title{
Reversible corticosubcortical FLAIR hypointensity in transient focal neurological episode
}

\author{
Dimitri Renard (ㄷ), Emilia El Houjeiry, Morgane Petot, Eric Thouvenot
}

CHU Nîmes, Univ. Montpellier,

Nimes, France

\section{Correspondence to} Professor Eric Thouvenot; eric.thouvenot@chu-nimes.fr

Accepted 20 July 2021

\section{DESCRIPTION}

A 69-year-old woman presented with transient spreading sensory symptoms in the left upper limb compatible with a transient focal neurological episode (TFNE). MRI performed 3.5 hours later revealed an acute focal right rolandic convexity subarachnoid hemorrhage (cSAH), seen as hyperintensity on fluidattenuated inversion recovery (FLAIR; figure 1A-C, arrows) and as hypointensity on T2*-weighted imaging (figure 1D, arrow). Associated FLAIR hypointensities were observed in the corticosubcortical brain areas adjacent to the cSAH (figure $1 \mathrm{~A}-\mathrm{C}$, arrowheads), with a mean signal intensity of 139 in the visually involved right perirolandic corticosubcortical area compared with a mean signal intensity of 174 in the contralateral left perirolandic corticosubcortical mirror area. Diffusion-weighted imaging (and apparent diffusion coefficient) were strictly normal. Multifocal cortical superficial siderosis on T2*-weighted imaging (figure 1E,F, arrowheads) evoked underlying cerebral amyloid angiopathy (radiological abnormalities corresponded to possible cerebral amyloid angiopathy according to the modified Boston criteria). Two weeks

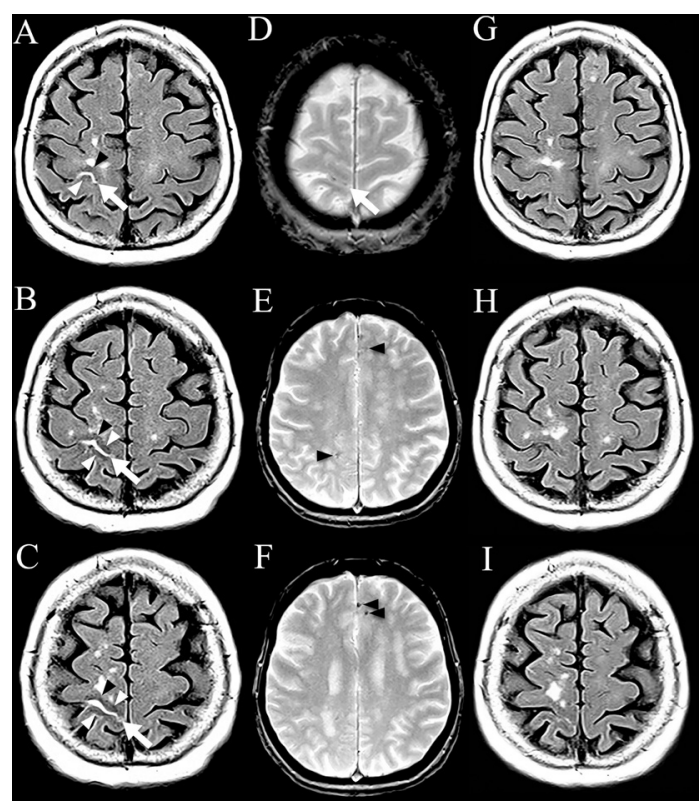

Figure $1 \mathrm{MRI}$ showing right rolandic CSAH seen as FLAIR hyperintensity (arrows) associated with hypointensity (arrowheads) in the adjacent cortex $(A-C)$. T2*-weighted imaging showed CSAH (D, arrow) and associated multifocal cortical superficial siderosis ( $E$ and $F$, arrowheads) evoking underlying cerebral amyloid angiopathy. Two weeks later, FLAIR signal changes normalised (G-I). CSAH, convexity subarachnoid hemorrhage; FLAIR, fluid-attenuated inversion recovery.

\section{Learning points}

- Transient subcortical fluid-attenuated inversion recovery hypointensity, thought to be related to non-haem iron (a feature of early ischaemia) accumulation and presence of free paramagnetic (because of their unpaired electrons) radicals possibly related with excitotoxic damage, can be observed in different brain disorders.

- Transient corticosubcortical signal changes (never earlier reported to the best of our knowledge) as observed in our patient presenting with acute focal convexity subarachnoid hemorrhage and transient focal neurological episode (TFNE) may help to better understand the underlying pathophysiology of symptoms in TFNE.

later, the subarachnoid and adjacent corticosubcortical FLAIR signal changes normalised (figure 1G-I), with a mean signal intensity of the corresponding earlier involved perirolandic corticosubcortical area of 172 on the right and 173 on the left side.

Transient subcortical FLAIR hypointensity has been described in different disorders, including seizures (often associated with non-ketonic hyperglycaemia), ischaemia, multiple sclerosis, leptomeningeal metastasis, meningitis/meningoencephalitis, Sturge-Weber syndrome, moyamoya disease. ${ }^{1-3}$ The decreased subcortical signal intensity on FLAIR is thought to be related to non-haem iron (a feature of early ischaemia) accumulation and presence of free paramagnetic (because of their unpaired electrons) radicals possibly related with excitotoxic damage.

The exact underlying pathophysiology of TFNE is unknown. The typically spreading nature of symptom onset, the short duration and the stereotyped character of symptoms suggest focal seizure activity, cortical spreading depression or local vasospasm, related to the presence of fresh blood or blood-breakdown products accumulating in superficial cortical layers of the involved sulci. ${ }^{4}$ Transient corticosubcortical signal changes (never earlier reported to the best of our knowledge) as observed in our patient presenting with acute focal cSAH and TFNE may help to better understand the underlying pathophysiology of symptoms in TFNE.

Contributors DR contributed to planning, conduct, reporting, conception and design, acquisition of data or analysis and interpretation of data. EEH contributed to planning, conduct, reporting, conception and design, acquisition of data or analysis and interpretation of data. MP contributed to planning, conduct, reporting, conception and design, acquisition of data or analysis 
and interpretation of data. ET contributed to planning, conduct, reporting, conception and design, acquisition of data or analysis and interpretation of data.

Funding The authors have not declared a specific grant for this research from any funding agency in the public, commercial or not-for-profit sectors.

Competing interests None declared.

Patient consent for publication Obtained.

Provenance and peer review Not commissioned; externally peer-reviewed.

\section{ORCID iD}

Dimitri Renard http://orcid.org/0000-0002-3511-8151

\section{REFERENCES}

1 Renard D, Le Floch A, Collombier L, et al. Lesion-related transient focal neurological deficit and subcortical FLAIR hypointensity. Acta Neurol Belg 2016;116:387-9.

2 Putta SL, Weisholtz D, Milligan TA. Occipital seizures and subcortical T2 hypointensity in the setting of hyperglycemia. Epilepsy Behav Case Rep 2014;2:96-9.

3 Lee JH, Na DG, Choi KH, et al. Subcortical low intensity on Mr images of meningitis, viral encephalitis, and leptomeningeal metastasis. AJNR Am J Neuroradiol 2002;23:535-42.

4 Charidimou A, Linn J, Vernooij MW, et al. Cortical superficial siderosis: detection and clinical significance in cerebral amyloid angiopathy and related conditions. Brain 2015:138:2126-39.

Copyright 2021 BMJ Publishing Group. All rights reserved. For permission to reuse any of this content visit https://www.bmj.com/company/products-services/rights-and-licensing/permissions/

BMJ Case Report Fellows may re-use this article for personal use and teaching without any further permission.

Become a Fellow of BMJ Case Reports today and you can:

- Submit as many cases as you like

- Enjoy fast sympathetic peer review and rapid publication of accepted articles

- Access all the published articles

- Re-use any of the published material for personal use and teaching without further permission

Customer Service

If you have any further queries about your subscription, please contact our customer services team on +44 (0) 2071111105 or via email at support@bmj.com.

Visit casereports.bmj.com for more articles like this and to become a Fellow 